\title{
THE PUBLIC ATTITUDE TOWARDS THE PROBLEMS OF PEOPLE WITH DISABILITIES AND THEIR READINESS FOR INTEGRATION THROUGH EMPLOYMENT
}

\author{
P. Stoevska* \\ PhD student, Department of Social Activities, Faculty of Medicine, Trakia University, Bulgaria \\ Lawyer at the Sofia Bar Association
}

\begin{abstract}
The focus of this article is on the attitudes of different social groups towards the problems of people with disabilities and their willingness to assist in the processes of their integration through work. For this purpose an empirical survey was conducted in the period October - December 2019 through anonymous paper and electronic questionnaires, including 28 questions, grouped in 5 sections. The survey covers 250 participants from across the country at different ages and with different sociodemographic profiles. The data are processed by the methods of descriptive statistics, as well as onedimensional and two-dimensional frequency analysis. The survey shows that a significant proportion of respondents demonstrate an understanding of the problems of people with disabilities, a willingness to help overcome the negative stereotypes towards disabled people with regard to their inclusion in the labor market. On the other hand, the general public is not sufficiently informed about the efforts of the government sector, human rights and non-governmental organizations on the labor integration of this vulnerable group, due to insufficient promotion of legislative and regulatory changes and their practical application in this field of social policy of the state. Another finding from the empirical study is that the opportunities for integration of persons with disabilities through work are not guaranteed both because of their lack of initiative and due to the existing manifestations of discrimination by some employers in the employment of persons with disabilities.
\end{abstract}

Key words: public attitudes; state policy; non-governmental sector; labor integration; people with disabilities

\section{INTRODUCTION}

In recent years, there has been a trend towards a change in society's attitude towards people with disabilities due to the increased awareness of the daily challenges faced by this vulnerable group and the active policy to improve their quality of life, including by creating conditions for employment. The UN Convention on the Rights of Persons with Disabilities (1) affirms the principles of equal opportunities for persons with disabilities through employment as a decisive factor for their social integration.

The effectiveness of policies for the social inclusion of people with disabilities through

\footnotetext{
*Correspondence to: Petya Stoevska, PhD student, Thracian University, Faculty of Medicine, Department of Social Activities, Lawyer at the Sofia Bar Association, E-mail: petyastoevska@pravniuslugi.eu
}

employment is hampered by the lack of a generally accepted definition of the terms "disability" and "people with disabilities". The World Health Organization (WHO) in its International Classification of Functioning, Disability and Health (ICF), taking into account the social aspects of disability, distinguishes two main concepts: insufficiency - loss or violation of psychological, physiological or physical structure or function and disability - limitation or loss of the ability to perform an activity in the manner or to an extent considered normal to a person without disability. (2)

The fact is that people treat the possibility of their employment differently. In the automated approach, labor is a value in itself. For the proponents of the instrumental approach, work for the individual is a means to achieve material well-being. According to the punitive approach, it is a "necessary evil." On the other hand, 
people are often divided on the basis of various criteria such as gender, age, skin color, social status, education, etc., and in the field of work into "working" and "non-working", "active" and "passive" etc. One of the most important criteria for differentiation in terms of professional realization is the so-called. dichotomous categorization, in which people are divided into "able-bodied" and "incapable", "capable" and "incapable", "able" and "incapable". Among some members of society there is still thinking about the self-marginalization of disabled people in the labor market, their social passivity and dependence on institutions. These factors have a demotivating effect on the desire of people with disabilities for their integration into society through employment.

Current statistics show that in our country people with disabilities are still poorly represented on the labor market and the working positions for them are extremely insufficient. According to data from the National Statistical Institute as of 2018 (3) there are over 465,000 people with permanent disabilities of working age in Bulgaria. Only $31 \%$ of them are employed and 5-6\% are registered as unemployed, i.e. $70 \%$ of these able-bodied people are not employed. Economic activity among people with disabilities is about $35 \%$. Research shows that our country has the potential to increase their employment by $30 \%$, which means that 120,000 to 130,000 new people can join the labor market. Support for the employment of this contingent is particularly relevant in the context of the implementation of the UN Convention on the Rights of Persons with Disabilities, the European Disability Strategy 2010-2020 (4), the Disability Act (5), and a number of other regulations. Policies for social inclusion through employment of people with disabilities are a multifaceted process that involves active action to encourage them to look for and find work, to support employers who want to offer jobs to people with disabilities and to change society's attitude to accept as equals such persons on the labor market. In other words, a significant part of these actions are aimed at both disabled and non-disabled people in a way that allows the social system to create appropriate conditions for employment of people from this vulnerable group, to overcome stigma, mistrust and negative attitudes towards their work potential.

In this context, both the way in which the general public perceives the problems of people with disabilities and the level of public awareness of measures to promote their employment and their willingness to integrate into the labor market are important.

The current study is largely influenced by the established two approaches to the problems of people with disabilities - medical and social. (6) The medical approach focuses on their deficits. In this model, the inability of people with disabilities to participate fully in public life is due not so much to the intolerant socio-cultural environment as to their "biological" dysfunction. The UN Convention on the Rights of Persons with Disabilities supports the social model in which disabilities are the result of interaction between persons with impaired functions and emotional barriers that hinder their effective social integration. European legislation affirms the view that disability is the result of a dynamic interaction between human health, age, gender, individuality and the impact of the socio physical environment in which a person with a disability lives. (4) The social approach focuses on the physical and intellectual capacity of the person with deficits. Apart from the moralethical arguments the economic ones are also important. In the conditions of demographic crisis and labor shortage on a European scale, it is more rational to invest in increasing the activity and quality of human capital among people with disabilities than to compensate for their deficits. The National Employment Action Plan for 2019 (7) provides for the active implementation of the new Law on People with Disabilities and the continuation of work on employment measures for this group. Due to the overall subsidy of the employers, their interest is combined with that of the disabled persons, who are employed for a period of two years. For the majority of them, this is the only opportunity to work. The employment of persons with and over $71 \%$ reduced working capacity is encouraged; military invalids; persons with sensory disabilities; people with mental disabilities. Priority is given to those employers who have concluded a contract for financing under Art. 25 of the Law on Integration of People with Disabilities (8) for providing access to workplaces, as well as for adaptation and / or equipment of workplaces for persons with disabilities. Another aspect of the present study is the impact of the life experiences of the participants. (9) Public attitudes towards people with disabilities may be a result of negative stereotypes, of the influence of the media, of the temporary or permanent contact with such people in cases where they are cared for daily in the family or as an employee in a social or 
health institution, even from the clichéd graphic visualization of the image of people with disabilities. Thus, if the general public demonstrates empathy and tolerance for the idea of social inclusion of the disabled, people who have direct experience in caring for people from this contingent in the family or professionally may express a different opinion on some of the issues raised in the study. The dynamics in the attitudes of people with disabilities themselves towards integration into society through work in the context of current legislative initiatives has also not been sufficiently studied. One of the aims of the study is to identify the amplitudes in the public mood on the topic, which on the one hand could help to clarify the ambivalent attitudes of society towards people with disabilities regarding their integration through employment and on the other hand to catalyze the pace for integration and creation of conditions for the labor realization of the persons with disabilities.

The multifaceted monitoring of public sentiment in the current empirical study aims to establish the level of awareness about the problems of people with disabilities; the readiness of the public to accept them as full members of society; the opinion of the respondents about their motivation and attitude to integrate into society through employment and the willingness of employers to hire people with different deficits.

\section{MATERIAL AND METHODS}

\section{Subject of research}

The subject of this study is the attitudes of people without disabilities and employers to the problems of people with disabilities and the readiness of this vulnerable group for integration into society through work. This complex analysis predetermines the methods and techniques for collecting information, on the basis of which the statistical data processing is carried out. The empirical study was conducted in the period October - December 2019 through voluntary and anonymous surveys on paper and on electronic media. The questionnaires, which have the character of an individualized interview, include 28 questions, grouped in 5 sections, aimed at ascertaining the personal opinion of the respondents at the time of the survey. Some of the questions suggest more than one possible answer, due to which the total sum of percentages of the answers to these questions exceeds $100 \%$. In some cases, respondents did not indicate any of the proposed response options, so the overall percentage of registered responses is below $100 \%$.

\section{Target group}

The choice of the target group is determined by the fact that the changes in the legislation concerning the labor integration of people with disabilities affect not only them but also the interests of the whole society. The opinion of 250 participants from all over the country with different ages and socio - demographic profiles was researched and analyzed, of which 100 people agreed to fill in a paper version of the survey. The other respondents indicated the answers in the electronic form of the survey. Both versions of the surveys are accompanied by a Declaration of Informed Consent, the content of which participants must familiarize themselves with in advance.

\section{Statistical processing}

In order to study the distribution of the variables, as well as to describe their possible categories, the methods of descriptive statistics, as well as one-dimensional and two-dimensional frequency analysis have been used. For this purpose, the number of units belonging to a given category is determined and the corresponding absolute or relative frequencies have been calculated (10). The empirical data have been processed through the program for processing and analysis of sociological data SPSS Statistics 17.0.0 WinWrap Basic, Copyright 1993-2007 (SPSS Statistics, 2007 - 17), and visualized through Excel 14.0.7237.5000, Ms Office Pro Plus 2010 (C) tables and charts, which allows better visibility and comparability of results, as well as summarizing the information (11).

\section{RESULTS AND DISCUSSION}

The arguments set out above determine the main aspects of the survey, which includes 28 questions, grouped in 5 sections, with the following focus:

Socio - demographic profile of the respondents

The data on the socio - demographic profile of the respondents have been summarized in Table 1. It can be concluded that the predominant number of participants who agreed to participate in the study were educated family women of active working age, living in a district town or those living on a family basis with their partner. These characteristics were expected to reflect on the responses from the following sections of the survey. 
Table 1. Socio-demographic profile of the respondents Number of persons

\begin{tabular}{|c|c|c|c|}
\hline & Respondents & $\begin{array}{r}\text { Relative } \\
\text { Share }(\%)\end{array}$ & $\begin{array}{l}\text { Number of } \\
\text { persons }\end{array}$ \\
\hline \multirow{2}{*}{ Gender } & Men & 28.8 & 72 \\
\hline & Women & 71.2 & 179 \\
\hline \multirow{4}{*}{ Age } & From $18-34$ & 32.4 & 81 \\
\hline & From $35-49$ & 29.2 & 73 \\
\hline & From $50-64$ & 11.2 & 28 \\
\hline & Over 65 & 27.2 & 68 \\
\hline \multirow{5}{*}{$\begin{array}{l}\text { Marital } \\
\text { Status }\end{array}$} & Married & 33.6 & 84 \\
\hline & Unmarried & 33.2 & 83 \\
\hline & Divorced & 10.4 & 26 \\
\hline & Widow/ Widower & 0 & 0 \\
\hline & Living with a partner & 15.6 & 39 \\
\hline \multirow{5}{*}{ Education } & $\begin{array}{l}\text { With higher education } \\
\text { (bachelor, master, with } \\
\text { acquired scientific degree / } \\
\text { title) }\end{array}$ & 56.0 & 140 \\
\hline & Student & 20.0 & 50 \\
\hline & $\begin{array}{l}\text { With secondary education, } \\
\text { incl. secondary special } \\
\text { education }\end{array}$ & 22.4 & 56 \\
\hline & With primary education & 0 & - \\
\hline & Didn't attend school & 0 & - \\
\hline \multirow{3}{*}{ Location } & District town & 69.2 & 173 \\
\hline & Small town & 24.0 & 60 \\
\hline & Village & 0 & - \\
\hline
\end{tabular}

II. Personal attitudes, emotional perceptions and interactions of the respondents in situations of communication with people with disabilities

Table 2. Personal attitudes, emotional perceptions and interactions of the respondents in situations of communication with people with disabilities

\begin{tabular}{|c|c|c|c|}
\hline Respondents & & $\begin{array}{l}\text { Relative } \\
\text { Share(\%) }\end{array}$ & $\begin{array}{r}\text { Number of } \\
\text { persons }\end{array}$ \\
\hline \multirow{3}{*}{$\begin{array}{l}\text { What are the reasons why } \\
\text { people with disabilities feel } \\
\text { isolated from the active life of } \\
\text { society? }\end{array}$} & $\begin{array}{l}\text { Due to physical, psychological, mental and } \\
\text { behavioral problems }\end{array}$ & 59.2 & 148 \\
\hline & $\begin{array}{l}\text { As a result of their personal decision not to } \\
\text { take an active part in the life of society }\end{array}$ & 12.0 & 30 \\
\hline & $\begin{array}{l}\text { Due to the difficult access to public, } \\
\text { educational and cultural institutions }\end{array}$ & 66.4 & 166 \\
\hline \multirow{4}{*}{$\begin{array}{l}\text { Indicate a term that you think } \\
\text { is more appropriate than the } \\
\text { term "people with disabilities" }\end{array}$} & Disadvantaged people & 50.0 & 125 \\
\hline & Disabled & 8.8 & 22 \\
\hline & $\begin{array}{l}\text { People with physical, health and mental } \\
\text { problems }\end{array}$ & 33.6 & 84 \\
\hline & None of the above & 8 & 20 \\
\hline \multirow{2}{*}{$\begin{array}{l}\text { Have you interacted with } \\
\text { people with disabilities? }\end{array}$} & Yes & 80.4 & 201 \\
\hline & No & 9.2 & 23 \\
\hline \multirow{5}{*}{$\begin{array}{l}\text { Do you often meet people with } \\
\text { disabilities on the street, in } \\
\text { public transport, in } \\
\text { educational and cultural } \\
\text { institutions? }\end{array}$} & Often & 27.2 & 68 \\
\hline & Sometimes & 46.8 & 117 \\
\hline & Rarely & 25.6 & 64 \\
\hline & Never & 0 & 0 \\
\hline & $\begin{array}{l}\text { I have met people with disabilities, but I have } \\
\text { not communicated with them }\end{array}$ & 10.4 & 26 \\
\hline \multirow{4}{*}{$\begin{array}{l}\text { How do you feel when you } \\
\text { meet a person with a } \\
\text { disability? }\end{array}$} & I feel sorry & 26.0 & 65 \\
\hline & Sympathy & 84.8 & 212 \\
\hline & Fear & 5.6 & 14 \\
\hline & Other opinion & 2.8 & 7 \\
\hline \multirow{3}{*}{$\begin{array}{l}\text { Would you help a person with } \\
\text { a disability in a situation where } \\
\text { he/she cannot cope on his/her } \\
\text { own? }\end{array}$} & Yes, if he /she wants to be helped & 75.2 & 188 \\
\hline & $\begin{array}{l}\text { No, if he /she does not want to be } \\
\text { helped }\end{array}$ & 2.8 & 7 \\
\hline & Depends on the situation & 24.0 & 60 \\
\hline
\end{tabular}


The attitude of the society towards people with disabilities has evolved in parallel with the terminology with which they are called. Outdated terms such as "idiot" and "moron" have been replaced over the years by terms "mentally retarded" and "disabled", "differently able", "incapable", "people with special needs", "people in need". Although in recent years the emphasis has been on the abilities of the individual and not on his disability, in the legislation and regulations in our country the concept of people with disabilities has been established, which, judging by the results of the survey, is not unambiguously perceived by respondents. Almost half of the respondents prefer the term "disadvantaged people"; for $33.6 \%$ of the participants the term "people with physical, health and mental problems" more adequately reflects the specific problems of this group; about 9\% of the participants in the survey still accept the term "disabled"; the lowest is the percentage of the respondents (8\%) who do not approve of any of the listed terms, but cannot indicate another more appropriate one.

The results of the study, presented in Table 2, lead to the conclusion that despite the complex socio - economic situation, the majority of respondents understand the problems of people with disabilities and demonstrate tolerance and empathy for this vulnerable part of society. Over $66 \%$ of the respondents are aware that the main reason for the feeling of isolation of people with disabilities from active public life is the accessibility of the environment; according to a significant percentage of the respondents (59\%), the social isolation of disabled people is a consequence of their physical, psychological, mental and behavioral problems; $12 \%$ believe that this is due to the personal decision of people with disabilities to distance themselves from the active life of the society.
STOEVSKA $P$.

The prevailing percentages of answers to the above question explain the results of the survey on the frequency of meetings with disabled people in an environment other than where they live. There is no data on a participant in the survey who has not met a person with a disability in public places; about $10 \%$ have met people with disabilities outside the environment in which they live but have not communicated with them; $25.6 \%$ of the respondents rarely met such persons in the situation indicated in the table; $27 \%$ often met people with disabilities outside their home; about $47 \%$ said they had sometimes met people with disabilities in public.

The opportunity to meet people with disabilities more often in public places allows others to understand their needs, problems and emotions. Empathy, which is the basis of constructive social communication, leads to the formation of altruistic behavior, which is confirmed by the answers to the last two questions in Table 2. Over $84 \%$ of the respondents feel sympathy for people with disabilities, and nearly $75 \%$ of them would help a disabled person in a situation in which he would not be able to cope on his own, but provided that he needs assistance. Although almost $26 \%$ feel sorry for people with disabilities, about $24 \%$ would respect their sense of dignity and help them depending on the situation. Only over $5 \%$ of respondents are afraid of interacting with people with disabilities. Interestingly, $2.8 \%$ of respondents who have other feelings for such people coincide with the percentage of those who would not help a disabled person if he/ she did not want to.

The degree of awareness of the respondents about the daily needs and problems of people with disabilities as a type of help they need, as well as the level of competence of the state bodies and institutions on which this help depends, are visualized from Figure 1 to Figure 4.

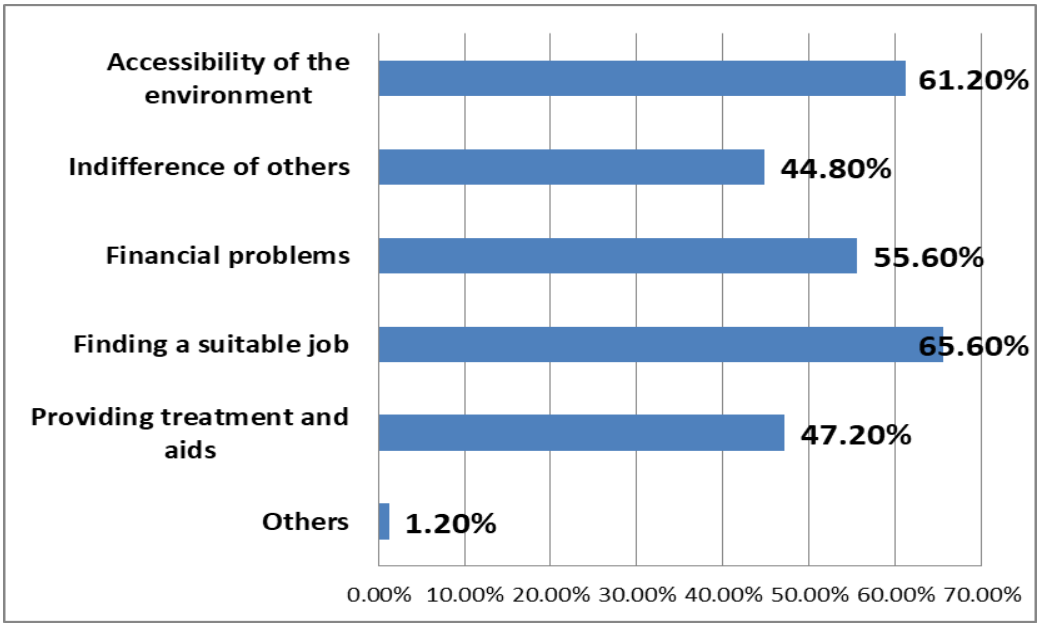

Figure 1. Awareness about the daily needs and problems of people with disabilities

Trakia Journal of Sciences, Vol. 18, Suppl. 1, 2020 
According to $65.6 \%$ of the respondents, the most significant problem for people with disabilities is finding a suitable job; for $61 \%$ this is the accessibility of the environment; $55.6 \%$ believe that people with disabilities are experiencing financial difficulties; $47.2 \%$ consider that the provision of adequate treatment and aids are important problems for the disabled; $48 \%$ of respondents believe that people with disabilities face the indifference of others $(44.8 \%)$

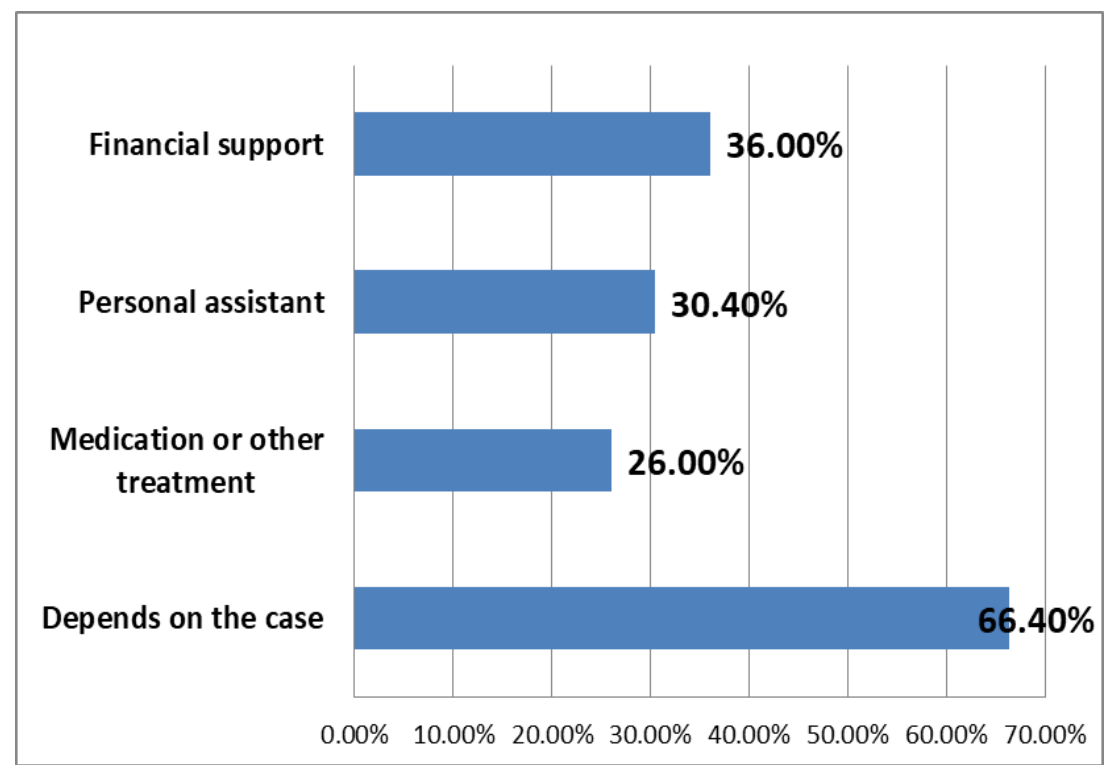

Figure 2. Type of help that people with disabilities need

About $66.4 \%$ of the respondents believe that the type of help that people with disabilities need depends on the specifics of their case; approximately $36 \%$ believe that they need financial assistance; $30.4 \%$ find that disabled need help of a personal assistant; according to $26 \%$ of the interviewees' medication or other treatment is essential for this group of people.

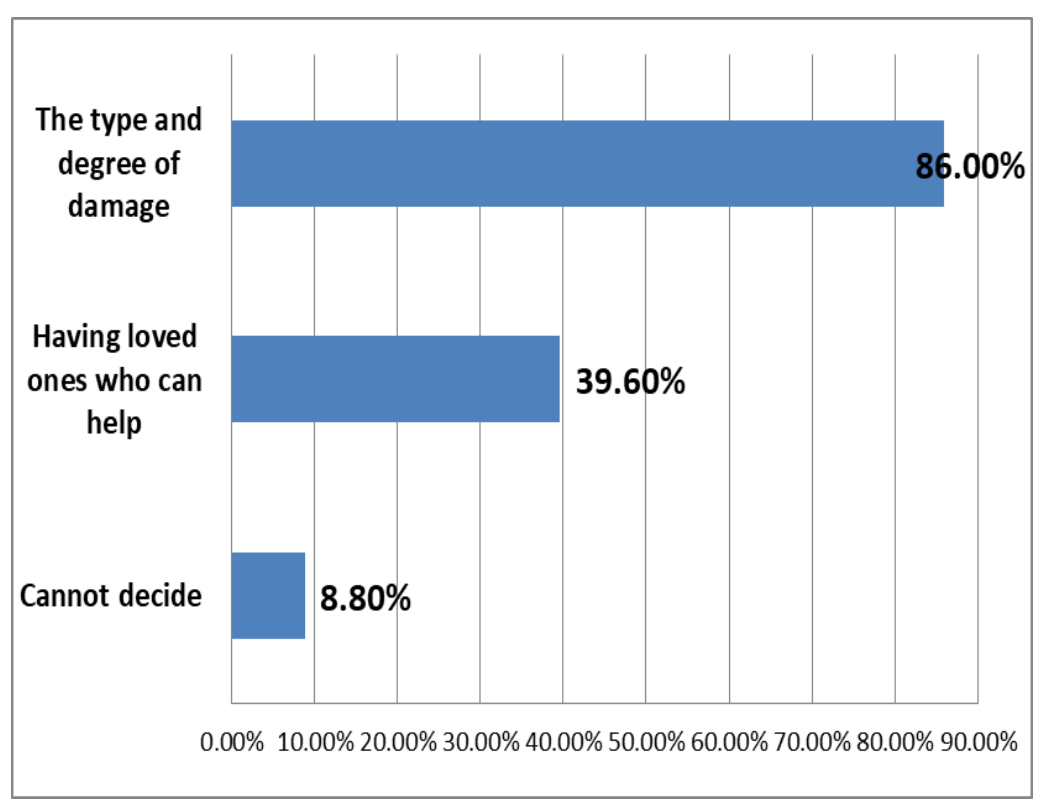

Figure 3. What factors are important in determining the type of assistance to people with disabilities

According to the data in Figure 3, 86\% of the respondents put in the first place the type and degree of disability as a factor on which the assistance for the disabled person depends.
About $39.6 \%$ believe that the determining factor is the presence of relatives who can help a person with a disability, and $8.8 \%$ cannot answer the question. 


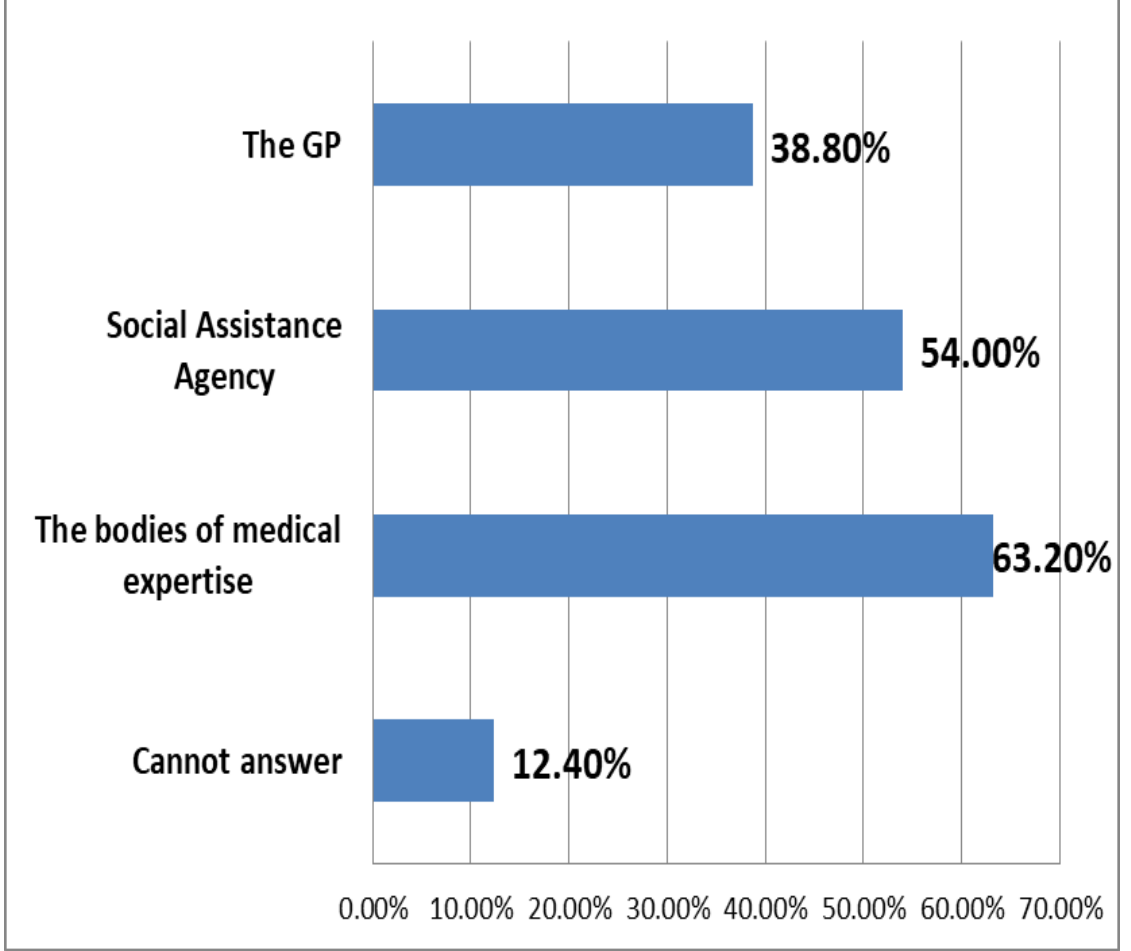

Figure 4. What factors are important in determining the type of assistance to people with disabilities

When asked about the competence of the bodies that have to assess the type and volume of assistance provided to disabled persons, $63.2 \%$ of the respondents trust the assessment of the bodies of the medical expertise; according to $54 \%$, the responsibility lies with the Social Assistance Agency; for 38.8\% these questions are within the competence of the GP; $12.4 \%$ cannot answer. (Figure 4)

The next part of the survey, related to the place and functioning of people with disabilities in the community, aims to establish the level of public awareness of some routine problems of people with severe disabilities and those in their immediate environment in view of two indisputable facts: 1) on the one hand, with the improvement of the access to health care and education, many of the chronic disability conditions become more manageable, and the possibilities of the persons with disabilities for social and labor integration - more and more realistic; 2) on the other hand, the policy of deinstitutionalization in recent years has removed a significant number of people with disabilities from the living and social environment in which they have lived for years, and which has made them dependent on this environment, has influenced their behavior, moral, value system of some persons with a disability, their motivation to integrate into society, including through work.
The questions in this section of the survey are summarized in Table $\mathbf{3}$ and cover the respondents' awareness of various aspects of life of people with disabilities in the community: housing; physical and financial support; access to medical services; accessibility of the environment: availability of convenient, financially secured transport and infrastructure; availability of flexible educational opportunities; employment opportunities: the attitude of people with disabilities to integrate into society through employment appropriate to their qualifications and abilities; the attitude of employers to hire a person with a disability.

The results of the answers in Table 3 , concerning the place of people with disabilities in the community, show a good level of awareness of the respondents on this issue: $77.3 \%$ of them believe that people with disabilities live in a family environment; $41.0 \%$ think they live in specialized institutions; $11.2 \%$ have no opinion on the matter. However, when asked where people with disabilities should live, $82.5 \%$ answered categorically that this should be a family-like environment; $23.5 \%$ agree that some should live in specialized institutions; only $8.0 \%$ cannot judge.

The results of the answers to the question concerning the public opinion about the place 
STOEVSKA P.

where adults with disabilities should study and work are similar. The figures in Table 3 shows that $66.5 \%$ of the respondents believe that these should be integrated educational institutions and enterprises, where they should have the opportunity to study and work together with persons without disabilities; about $36 \%$ believe that specialized schools and companies are, where the conditions are tailored to the specific needs of these people, are more suitable for them; $14.3 \%$ find that for some people with disabilities it is better to study and work at home; only $8.4 \%$ have no opinion.

Table 3. Place and functioning of people with disabilities in the community

\begin{tabular}{|c|c|c|c|}
\hline Respondents & & $\begin{array}{l}\text { Relative } \\
\text { Share }(\%)\end{array}$ & $\begin{array}{l}\text { Number } \\
\text { of } \\
\text { persons }\end{array}$ \\
\hline \multirow{3}{*}{$\begin{array}{l}\text { Where do you think people with } \\
\text { disabilities live? }\end{array}$} & $\begin{array}{l}\text { I specialized institutions for people } \\
\text { with disabilities }\end{array}$ & 41.2 & 103 \\
\hline & In a family environment & 77.6 & 194 \\
\hline & Cannot answer & 11.2 & 28 \\
\hline \multirow{3}{*}{$\begin{array}{l}\text { Where do you think people with } \\
\text { disabilities should live? }\end{array}$} & In a family-like environment & 82.8 & 207 \\
\hline & $\begin{array}{l}\text { In specialized institutions for people } \\
\text { with disabilities }\end{array}$ & 20.0 & 50 \\
\hline & Cannot answer & 8.0 & 20 \\
\hline \multirow{4}{*}{$\begin{array}{l}\text { Where do you think adults with } \\
\text { disabilities should study and } \\
\text { work? }\end{array}$} & $\begin{array}{l}\text { In specialized } \quad \text { schools } \quad \text { and } \\
\text { enterprises }\end{array}$ & 35.6 & 90 \\
\hline & $\begin{array}{l}\text { In integrated schools and enterprises } \\
\text { together with people without } \\
\text { disabilities }\end{array}$ & 66.8 & 167 \\
\hline & At home & 14.4 & 36 \\
\hline & Cannot decide & 8.4 & 21 \\
\hline
\end{tabular}

The results of this section of the study confirm the high level of awareness regarding the environment of residence, training and work of people with disabilities, as well as the attitude of society to bring them out of isolation, providing them with conditions to live in a family environment or in a family-friendly environment to study and work with people without disabilities.

\section{$I V$. Awareness of the respondents about the current changes in the legislation concerning people with disabilities and the changes in the Ordinance on medical expertise. \\ The analysis of the data from the first two questions in Table 4 confirms the public interest in the changes in legislation and regulations related to people with disabilities, for two main reasons: according to 56\% of respondents these changes are not addressed only to disabled people and affect the interests of society as a whole; $34 \%$ of the respondents accept the changes because they believe that the previous legislation harms the disabled. The share of $22 \%$ of respondents, who do not have information about these changes, is significant.}

Although about $18 \%$ approve of the amendments to the Law on People with Disabilities (PWD) as in line with European legislation, over $40 \%$ of respondents believe that it does not take into account the individual needs of disabled people. The fact that over $42 \%$ do not have information about the changes in PWD confirms the need for active promotion of legislative initiatives and their practical application in order to improve the quality of life and integration of people with disabilities in society.

The answers to the question concerning the new Ordinance on medical expertise are worrying. Almost $47.0 \%$ are not aware of the changes in this important normative act; over $36 \%$ do not approve of the criteria for determining the percentage of incapacity for work as unfair and harmful to people with disabilities; only $17.2 \%$ find them fairer than the old criteria. In addition; $61.2 \%$ is the percentage of those who do not notice a significant change in society's attitude towards people with disabilities; about $35 \%$ are of the opposite opinion, and only $4.0 \%$ cannot answer the question (Table 4). 
STOEVSKA P.

Table 4. Awareness of the respondents about the current changes in the legislation and regulations concerning people with disabilities

\begin{tabular}{|c|c|c|c|}
\hline Respondents & & $\begin{array}{l}\text { Relative } \\
\text { Share(\%) }\end{array}$ & $\begin{array}{c}\text { Number of } \\
\text { persons }\end{array}$ \\
\hline \multirow{3}{*}{$\begin{array}{l}\text { Are you interested in changes in } \\
\text { legislation related to people with } \\
\text { disabilities }\end{array}$} & $\begin{array}{l}\text { Yes, because I believe that } \\
\text { previous legislation harms } \\
\text { people with disabilities }\end{array}$ & 34.0 & 85 \\
\hline & $\begin{array}{l}\text { Yes, because these } \\
\text { changes affect the whole } \\
\text { society }\end{array}$ & 56.0 & 140 \\
\hline & I am not informed & 22.0 & 55 \\
\hline \multirow{3}{*}{$\begin{array}{l}\text { Do you approve the changes in the } \\
\text { Law on People with Disabilities? }\end{array}$} & $\begin{array}{l}\text { Yes, because they comply } \\
\text { with European legislation }\end{array}$ & 17.6 & 44 \\
\hline & $\begin{array}{l}\text { No, because they do not } \\
\text { take into account the } \\
\text { individual needs of people } \\
\text { with disabilities }\end{array}$ & 40.4 & 101 \\
\hline & I am not informed & 42.4 & 106 \\
\hline \multirow{3}{*}{$\begin{array}{l}\text { Do you approve the changes in the } \\
\text { Ordinance on medical expertise? }\end{array}$} & $\begin{array}{l}\text { Yes, because the criteria } \\
\text { for determining the } \\
\text { percentage of working } \\
\text { capacity are fairer }\end{array}$ & 17.2 & 43 \\
\hline & $\begin{array}{l}\text { No, because the criteria for } \\
\text { determining the percentage } \\
\text { of working capacity are } \\
\text { not fair and harm people } \\
\text { with disabilities }\end{array}$ & 36.4 & 91 \\
\hline & I am not informed & 46.8 & 117 \\
\hline \multirow{3}{*}{$\begin{array}{l}\text { Have you noticed a change in society's } \\
\text { attitude towards people with } \\
\text { disabilities? }\end{array}$} & $\begin{array}{l}\text { There is a significant } \\
\text { change }\end{array}$ & 35.2 & 88 \\
\hline & $\begin{array}{l}\text { There is no a significant } \\
\text { change }\end{array}$ & 61.2 & 153 \\
\hline & Cannot answer & 4.0 & 9 \\
\hline
\end{tabular}

The fluctuations in the public opinion regarding the normative changes concerning the people with disabilities impose the conclusion that the actions in this direction should be preceded by a wide public discussion and should go in parallel with their popularization. Due to the length of the consultation process and the complexity of the legislative technique, it takes time for the changes not only to come into force but also to achieve the desired effect both among their addressee and the general public, on which largely depends the implementation of new government policies in this area and changes in public attitudes towards people with disabilities.

\section{Public attitude towards people with disabilities to be included in the educational and production process}

The result of the aspiration of the state institutions to make the employment of people with disabilities a national priority is the developed Long-Term Employment Strategy for People with Disabilities 2011 - 2020 (12), which is based on the recommendations of the Council of Europe, the UN Convention on the Rights of Persons with Disabilities, the UN Standard Rules on Equality and Equal Opportunities.

The last section of the survey aims to identify several important aspects of the research topic: the attitude of society to people with disabilities to be included in the educational and production process as full members of society; the causes of unemployment among a significant part of this contingent; the motivation of disabled people to look for work or start their own business; the willingness of employers to hire people with deficits of different nature and degree. Respondents' views on the overall change in society's attitudes towards disabled, and in particular towards their inclusion in the educational and work process, are summarized in Table 5. 
STOEVSKA P.

Table 5. Public attitude towards people with disabilities to be included in the educational and production process

\begin{tabular}{|c|c|c|c|}
\hline Respondents & & $\begin{array}{l}\text { Relative } \\
\text { Share }(\%)\end{array}$ & $\begin{array}{c}\text { Number of } \\
\text { person }\end{array}$ \\
\hline \multirow{4}{*}{$\begin{array}{l}\text { How would the inclusion of people } \\
\text { with disabilities affect the } \\
\text { educational and production process? }\end{array}$} & $\begin{array}{l}\text { It will help to better } \\
\text { understand the problems of } \\
\text { people with disabilities }\end{array}$ & 66.0 & 165 \\
\hline & $\begin{array}{l}\text { It will complicate the } \\
\text { learning and production } \\
\text { process }\end{array}$ & 6.0 & 15 \\
\hline & $\begin{array}{l}\text { It will not affect the learning } \\
\text { and production process }\end{array}$ & 20.0 & 50 \\
\hline & I find it difficult to answer & 16.4 & 41 \\
\hline \multirow{3}{*}{$\begin{array}{l}\text { Have you noticed a change in } \\
\text { society's attitude towards people } \\
\text { with disabilities? }\end{array}$} & There is a significant change & 35.2 & 88 \\
\hline & $\begin{array}{l}\text { There is no a significant } \\
\text { change }\end{array}$ & 60.8 & 152 \\
\hline & Cannot answer & 4.0 & 10 \\
\hline \multirow{5}{*}{$\begin{array}{l}\text { Has the attitude of people with } \\
\text { disabilities to look for work } \\
\text { changed? }\end{array}$} & Yes & 38.4 & 96 \\
\hline & No & & \\
\hline & Have no opinion & 28.0 & 70 \\
\hline & & 33.6 & 84 \\
\hline & Yes & 23.2 & 58 \\
\hline \multirow{2}{*}{$\begin{array}{l}\text { Do you know people with disabilities } \\
\text { who have started their own business? }\end{array}$} & No & 62.8 & 157 \\
\hline & Cannot answer & 14.0 & 35 \\
\hline \multirow{3}{*}{$\begin{array}{l}\text { Do you know employers with } \\
\text { disabilities who have hired other } \\
\text { people with disabilities? }\end{array}$} & Yes & 9.6 & 24 \\
\hline & No & 58.8 & 147 \\
\hline & Cannot answer & 31.6 & 79 \\
\hline \multirow{3}{*}{$\begin{array}{l}\text { Has the attitude of employers to hire } \\
\text { people with disabilities changed? }\end{array}$} & Yes & 24.4 & 61 \\
\hline & No & 52.0 & 130 \\
\hline & Cannot answer & 23.6 & 59 \\
\hline
\end{tabular}

The results of the answers to the first question in Table 5 shows that for $66 \%$ of the respondents the inclusion of people with disabilities in the educational and production process will help to better understand their problems; $20 \%$ are of the opinion that the participation of such persons will not affect the course of the educational and labor process; about $16 \%$ find it difficult to assess and only $6 \%$ believe that disabled people would complicate both processes. The majority of respondents reject discrimination on the grounds of disability and support the policy of integration of people with disabilities through education and work as a way to ensure equal opportunities and a dignified life for this vulnerable group.

However, these optimistic figures do not correspond to the answers to the question concerning the change in society's attitude towards people with disabilities: approximately $61 \%$ believe that there is no significant change in this regard; $35.2 \%$ are of the opposite opinion; about $4 \%$ cannot answer.
Although according to the survey the majority of respondents support the integration of people with disabilities by including them in appropriate forms of training and employment, the opinion of respondents about the attitude of people with disabilities to integrate into society through their work is ambiguous. According to $38 \%$, there is a positive tendency in the attitude of disabled people to look for work; approximately $34 \%$ have no opinion on the issue and $28 \%$ give a negative answer. Judging by the data, $63 \%$ of respondents do not know people with disabilities who have started their own business; $23 \%$ know such people, and about $14 \%$ cannot answer.

The data on employers with disabilities who have hired other people with disabilities are worrying: $59 \%$ of the respondents do not know such employers; $31.6 \%$ cannot answer the question and only about $10 \%$ answer positively to this question. It must be concluded that public opinion is critical of both the employment of people with disabilities in their job search and their attitude to earn income from their own activities, as well as their 
STOEVSKA $P$.

willingness to hire other people with disabilities as employers.

On the other hand, the participants in the empirical study are aware of the role of business in the adequate integration of people with disabilities into the labor market. The answers to the last question in Table №5 follow the dynamics of the labor realization of people with disabilities through the prism of the activity of employers. 52\% of the respondents answered that there is no change in the attitude of employers to hire people with disabilities; almost equal is the percentage of those who think that employers are willing to hire disabled people (24.3\%) compared to those who cannot answer this question $(23.5 \%)$.

The data from this part of the survey lead to the conclusion that despite of the developed strategies to promote the employment of people with disabilities and governmentsupported programs to encourage employers to hire such people, the results are still far from the expectations of the affected persons.

\section{CONCLUSION}

The results of the survey confirm that personally the majority of respondents demonstrate tolerance, awareness and understanding of the problems of people with disabilities, willingness to assist in the process of overcoming stereotypes and desegregation of this vulnerable group. However, tolerance is a multifaceted process. The study confirms that despite the active state policy aimed at social inclusion of people with disabilities, measures in this direction are not sufficiently promoted and the general public is not informed about the efforts of the government sector, human rights and non-governmental organizations for the integration of people with disabilities. In various spheres of public life including through their participation in the labor market.

The data from the survey show that the right to work of people with disabilities is not guaranteed both due to the lack of initiative of people with disabilities themselves and due to the fact that they are still subject to discrimination when applying for a job.

\section{REFERENCES}

1. UN Convention on the Rights of Persons with Disabilities (2006)

2. The United Nations and Disabled Persons The First Fifty Years

(https://www.un.org/esa/socdev/enable/dis5 0y10.htm)

3. National Statistical Institute. Labor Force Survey in 2018. Employment of People with Disabilities. Additional module to the Labor Force Survey in 2011.

4. European Disability Strategy 2010-2020 (https://eur-lex.europa.eu/legalcontent/EN/TXT/HTML/?uri=CELEX:520 10DC0636\&from=EN)

5. Law on People with Disabilities (2019)

6. People with disabilities. (two approaches to the problem of people with disabilities)https://www.britishcouncil.bg/p rogrammes/society/mediadiversity/disabilities

7. The National Action Plan for Employment in 2019 (www.strategy.bg >FileHandler

8. Law on the Integration of People with Disabilities (2018)

9. The economic activity of the young people on the territory of the town of Lom. Analytical report. (Results of an empirical study)

http://miglom.org/documents/Analitichen_d oklad_2018-2.pdf

10. Veleva, P. 2019, Introduction to statistical methods. Chapter II of the monograph: Statistical software for experimental data processing, Reviewers: Galya Kozhuharova and Yanka Tsvetanova, Academic Publishing House Thracian University Stara Zagora, ISBN: 978-954-338-152-4 (in Bulgarian)

11.SPSS Statistics 17.0.0 WinWrap Basic, Copyright 1993-2007 Polar Engineering and Consulting. 18. Excel 14.0.7237.5000 Microsoft Office Professional Plus $2010^{\circ}$, 2010 Microsoft Corporation

12.Long-term strategy for employment of people with disabilities $2011-2020$. 